\title{
The Multifaceted Role of T-Helper Responses in Host Defense against Aspergillus fumigatus
}

\author{
Intan M. W. Dewi ${ }^{1,2}$, Frank L. van de Veerdonk ${ }^{1}$ and Mark S. Gresnigt ${ }^{1, *}$ \\ 1 Department of Experimental Internal Medicine and Radboud Center for Infectious Diseases (RCI), \\ Radboud University Medical Center, Geert Grooteplein Zuid 10, 6525 GA Nijmegen, The Netherlands; \\ Intan.Dewi@radboudumc.nl (I.M.W.D.); Frank.vandeVeerdonk@radboudumc.nl (F.L.v.d.V.) \\ 2 Faculty of Medicine Universitas Padjadjaran, Jl. Eijkman No. 38, Bandung 40161, Indonesia \\ * Correspondence: Mark.Gresnigt@radboudumc.nl; Tel.: +31-24-36-16636
}

Received: 1 September 2017; Accepted: 30 September 2017; Published: 4 October 2017

\begin{abstract}
The ubiquitous opportunistic fungal pathogen Aspergillus fumigatus rarely causes infections in immunocompetent individuals. A healthy functional innate immune system plays a crucial role in preventing Aspergillus-infection. This pivotal role for the innate immune system makes it a main research focus in studying the pathogenesis of aspergillosis. Although sometimes overshadowed by the innate immune response, the adaptive immune response, and in particular T-helper responses, also represents a key player in host defense against Aspergillus. Virtually all T-helper subsets have been described to play a role during aspergillosis, with the Th1 response being crucial for fungal clearance. However; morbidity and mortality of aspergillosis can also be partly attributed to detrimental immune responses resulting from adaptive immune activation. Th2 responses benefit fungal persistence; and are the foundation of allergic forms of aspergillosis. The Th17 response has two sides; although crucial for granulocyte recruitment, it can be involved in detrimental immunopathology. Regulatory T-cells, the endogenous regulators of inflammatory responses, play a key role in controlling detrimental inflammatory responses during aspergillosis. The current knowledge of the adaptive immune response against A. fumigatus is summarized in this review. A better understanding on how T-helper responses facilitate clearance of Aspergillus-infection and control inflammation can be the fundamental basis for understanding the pathogenesis of aspergillosis and for the development of novel host-directed therapies.
\end{abstract}

Keywords: aspergillosis; T-helper cells; adaptive immune response; immunopathology

\section{Introduction}

Infections with Aspergillus spp. have emerged as important opportunistic fungal pathogens in patients with a severely compromised immune system such as those receiving solid organ transplant (SOT) [1,2] and hematopoietic stem cell transplantation (HSCT) [3]. A fully functional innate immune system is required to prevent the conidia, which are inhaled on a daily basis, from causing life-threatening infections. In particular, the lack of innate effector cells, such as neutrophils, and pleiotropic impairment of immune activation by immunosuppressive therapies such as corticosteroids, are the most important factors predisposing patients to invasive aspergillosis [4-7]. Therefore, the innate immune response has been a point of major interest in the study of the pathogenesis of aspergillosis [8-14]. Nevertheless, recently it has become apparent that the adaptive immune response, and in particular T-helper responses also play a crucial role in pulmonary host defense [15] and the pathogenesis of aspergillosis [16]. The primary role of T-helper responses in pulmonary host defense is to augment and organize the innate immune response to deal more efficiently with invading pathogens. However, morbidity and mortality of aspergillosis can also be partly attributed to immunopathology resulting from exaggerated adaptive immune activation. 
This review describes how T-helper responses are induced during host defense against Aspergillus spp. and in particular the most common species A. fumigatus. Distinct T-helper subsets and their roles in protective immunity against Aspergillus will be reviewed, followed by their role in allergic responses and detrimental immunopathology. Finally, it is discussed how immune-based therapies can make use of features of the adaptive immune system and/or its effector functions to improve the outcome of aspergillosis.

\section{Induction of T-Helper Responses by the Innate Immune System}

The activation and expansion of T-helper subsets cannot be exclusively induced by the infection alone and requires innate immune mechanisms. Following inhalation, Aspergillus conidia encounter a wide variety of innate immune barriers in the lung.

The airway epithelial cells represent the most prominent barrier against infection; they play a major role in recruitment, activation and skewing of T-cell subsets by influencing the inflammatory cytokine environment [17-20]. Resident alveolar macrophages (AM) engulf conidia and release different cytokines and chemokines, including TNF $\alpha$, MIP1- $\alpha$, IL-1 $\beta$, IL- $1 \alpha$, IL-6, G-CSF and GM-CSF [21], leading to further recruitment of innate effector cells including the dendritic cells (DCs) [9]. Monocytes also contribute significantly to the induction of T-helper responses during Aspergillus-infection, which is thought to be mediated through their differentiation into CD11 $\mathrm{b}^{+}$ DCs [22].

Dendritic Cells (DCs) are the key players in bridging the innate and adaptive immune response against $A$. fumigatus by specifically activating naïve $\mathrm{CD} 4^{+} \mathrm{T}$-cells and triggering their differentiation into disparate lineages of effector cells [23] (Figure 1). Pulmonary DCs of mice infected with A. fumigatus undergo maturation upon migration, shown by increased expression of the T-cell stimulatory molecules CD80 and CD86 [24]. In addition, upon engulfment of conidia, DCs induce the migration of T-helper cells by releasing the chemokines CCL3, CCL4, CXCL10 and CCL20 [25]. Antigen presentation and T-cell activation is initiated by binding of the T-cell receptor (TCR) to major histocompatibility complex (MHC) class II, followed by interaction of co-stimulatory molecules present on the surface of T-cells and antigen presenting cells (APCs). Interaction of CD28 on T-cell surface with its ligand CD80 (B7-1) or CD86 (B7-2) on APCs and OX40 with OX40L has been shown to contribute to the immunological process of allergic forms of aspergillosis [26]. After antigen presentation and co-stimulation, autocrine production of IL-2 allows T-cells to proliferate and the cytokine milieu determines their differentiation into distinct effector cells [24,27-30] (Figure 1). The cytokine milieu is partly determined by the morphology and cell wall components of $A$. fumigatus that are recognized by the DCs [29]. Human DCs, stimulated with A. fumigatus conidia, trigger significant production of IL-12, which is the main cytokine inducing IFN $\gamma$-producing T-cells [27]. Different subsets of DCs exhibit distinct responses to the fungus, where monocyte-derived DC (moDC) and myeloid DC (mDC) show greatest similarities, producing pro-inflammatory cytokines IL-1 $\beta, \mathrm{TNF} \alpha$, chemokines IL-8, CXCL1, as well as anti-inflammatory cytokines IL-4 and IL-10 specifically upon stimulation with hyphae [24,28]. TNF $\alpha$ release by DCs can determine whether Th17 or Th2 responses are induced leading to either neutrophil or eosinophil-mediated inflammation [30]. Infection of human DCs with Aspergillus hyphae but not dormant conidia results in abundant production of IL-23, subsequently inducing a Th17 response [31]. Signaling induced by cytokines binding to their complementary receptors lead to induction of lineage-specific transcription factors, that act as master regulators of distinct effector functions, helping the T-helper lineages to each exert their unique function in host defense against aspergillosis. 


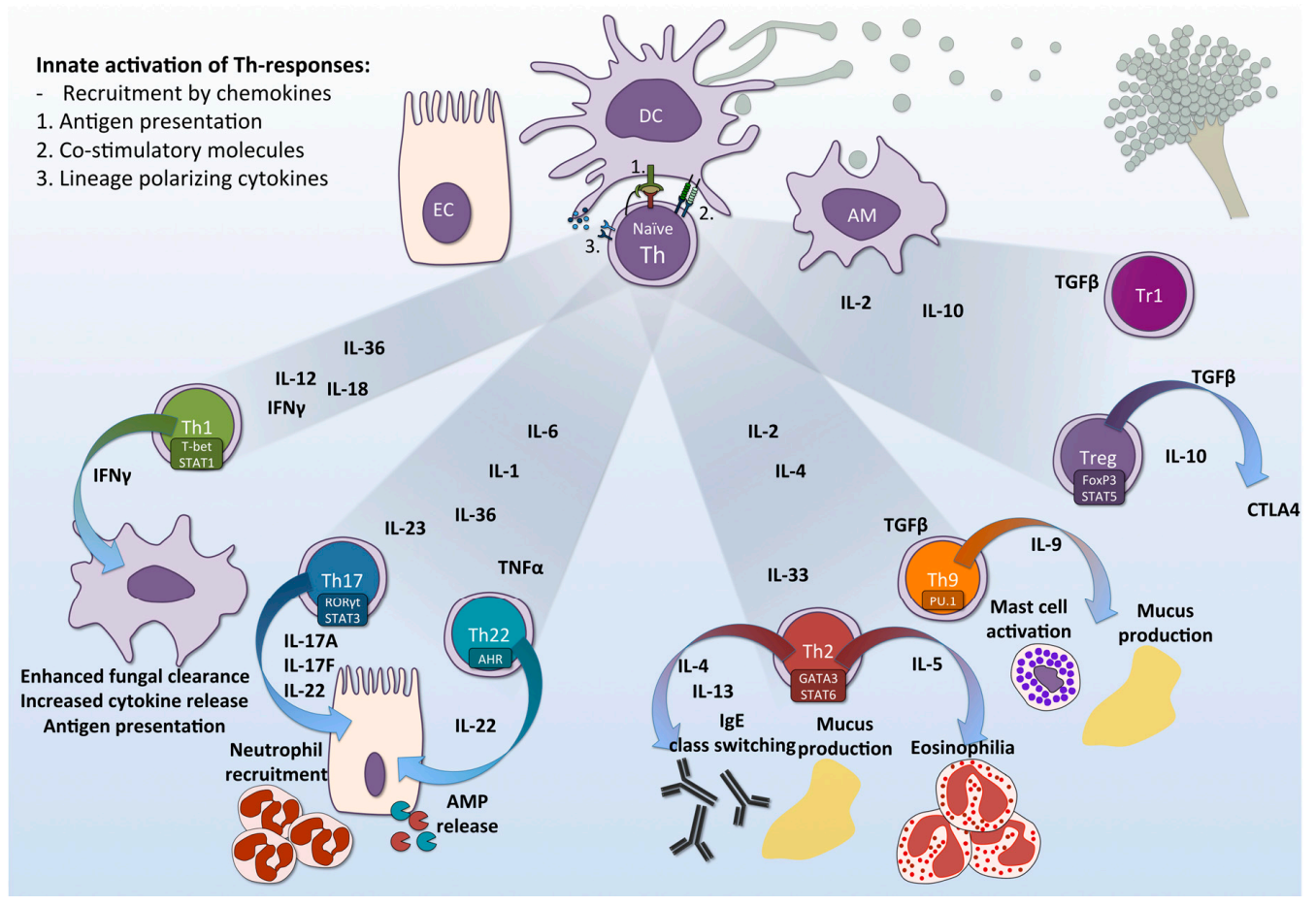

Figure 1. T-helper responses to A. fumigatus. The epithelial cell (EC), dendritic cell (DC) and alveolar macrophage (AM) constitute the innate immune response against $A$. fumigatus. Engagement of surface pattern recognition receptors (PRRs) on these cells triggers downstream signaling pathway, leading to production of distinct lineage-polarizing cytokines. This, in combination with antigen presentation by via MHC-II and binding of co-stimulatory molecules, in turn lead to activation and differentiation of naïve CD4 ${ }^{+}$T-helper cells to distinct effector lineages: Th1, Th17, Th22, Th2, Th9, Treg and Tr1. These effector cells differentially contribute to either protection against fungal infection, detrimental immunopathology, or in the regulation of the adaptive immune response. EC = Epithelial cell; $\mathrm{DC}=$ Dendritic cells; $\mathrm{AM}=$ Alveolar macrophages; $\mathrm{Th}=\mathrm{T}$-helper cells; IL = Interleukin; IFN = Interferon; $\mathrm{TGF}=$ Transforming growth factor; TNF = Tumor necrosis factor; $\mathrm{AMP}=$ antimicrobial peptide; CTLA-4 = cytotoxic T-lymphocyte antigen 4; STAT = Signal Transducer and Activator of Transcription, $\mathrm{ROR} \gamma \mathrm{t}=\mathrm{RAR}$-related orphan receptor gamma $\mathrm{t}$; AHR = aryl hydrocarbon receptor; $\mathrm{t}-\mathrm{Bet}=\mathrm{T}$-box transcription factor 21; GATA3 = Transcription factor GATA-3; PU.1 = Transcription factor PU.1; FOXP3 = Forkhead box P3.

\section{T-Helper Responses in Aspergillosis}

Recently, all three major T-helper lineages, Th1, Th2 and Th17, have been demonstrated to play important roles during aspergillosis. Aspergillus-antigen specific T-cells have been found in patients as well as healthy individuals [32-34], and in animal models of Aspergillus-infection [35,36]. Inoculation with a low dose of $A$. fumigatus conidia or culture filtrate can induce resistance and protection against subsequent infection in a murine model for invasive pulmonary aspergillosis; indicating the protective role of Aspergillus-specific T cells in antifungal defense [36]. T-cells specific to fungal catalase and Crf1 that express CD154 and IFN $\gamma$ were identified in patients recovering from invasive aspergillosis, whereas these cells were absent in patients with progressive infection [33]. These cells with a Th1 phenotype in recovering patients highlight the importance of this subset in clearing the infection [33].

In addition, murine models for aspergillosis have recently demonstrated that a dominant Th1 response is required for resistance to aspergillosis and induction of an efficient antifungal response [36-38]. Its induction relies on the Th1 inducing cytokine IL-12, which is induced in high amounts in mice that are resistant to aspergillosis [27,36,39]. IL-18, a member of the IL-1 family of cytokines is also a key player in activation of Th1 and induction of IFN $\gamma$, but only a few studies have 
investigated IL-18 in anti-Aspergillus host defense. Immunocompetent mice infected with A. fumigatus show elevated IL-18 in bronchoalveolar lavages and lung tissues [40], which could suggest a role for IL-18 in host defense against Aspergillus. However, further studies are required to elaborate the role of this cytokine in aspergillosis. The protection mediated by the Th1 subset correlates with the production of the cytokine IFN $\gamma$ [36], which potentiates the fungicidal activity of innate immune cells [41-44]. Collectively, these studies emphasize the crucial role of the Th1 response in protection against Aspergillus, but not all T-helper responses promote clearance of the fungus from the lungs.

The Th2 response that is characterized by production of IL-4, IL-5, IL-13 and IL-10, mediates anti-inflammatory responses, allergy, and fungal persistence in the lungs [45]. The fact that a shift towards Th1 rather than Th2 is required for protection is especially highlighted in IFN $\gamma$ deficient mice with an impaired protective antifungal immunity, and excessive Th2 responses [46]. A robust Th2 response is associated with a poor outcome of aspergillosis in murine models [35,46], and these responses neutralize protective Th1 responses mediated through the cytokine IL-4 [46]. In addition, IL-10 released by Th2 cells also negatively impacts protective Th1 responses in aspergillosis models, by suppressing pro-inflammatory cytokines and chemokines, inhibiting T-cell activation and IFN $\gamma$ production, and promoting a Th2 response [47]. Bronchial epithelial cell stimulation with A. fumigatus activates protease receptor (PAR-2) and PTPN11 (SHP2), a phosphatase that inhibits IFN signaling, hence skewing the T-cell response preferably to Th2 [48]. IL-33, another IL-1 family member and a Th2-inducing cytokine, is highly expressed in mice stimulated with viable A. fumigatus conidia and is known to mediate immunopathology in response to chronic allergen airway exposure [49]. An elevated IL-33 level is associated with SAFS [50].

The mechanisms of protection against aspergillosis seemed to be very well explained by a balanced Th1 and Th2. However, with the description of the Th17 subset in 2005 [51], the understanding of how T-helper responses mediate protection against aspergillosis had to be revisited.

\section{The Two Faces of the Th17 Response}

The innate cytokines IL-1 (IL-1 $\beta$ and IL-1 $\alpha$ ), IL-23 and IL- 6 induce Th17 differentiation by activation of the signature transcription factor of Th17 cells, retinoic acid receptor-related orphan receptor ROR $\gamma \mathrm{T}$ [52]. In addition, novel IL-1 cytokines IL-36 $\alpha, \beta, \gamma$ and IL-36Ra can also regulate the induction of Th17 responses by Aspergillus [53]. The hallmark of Th17 cells is the production of IL-17A and IL-17F, which trigger the recruitment and activation of neutrophils to the site of infection, as well as inducing pro-inflammatory cytokines IL-6, IL-1 $\beta$, G-CSF and TNF $\alpha$; and chemokines CXCL8, MIP-1 and MCP1. Potentiation of neutrophils by IL-17A enhances production of ROS, proteolytic enzymes and antimicrobial peptides, altogether aiming at fungal elimination [54-56]. Upon activation, Th17 cells also release IL-22, which triggers epithelial cells to produce antimicrobial peptides such as $\beta$-defensin 2 and lipocalin-2 [57].

Particularly, engagement of dectin-1 on antigen-presenting cell signals through Syk/CARD9, leading to cytokine profiles that polarize naïve $\mathrm{CD}^{+}{ }^{+} \mathrm{T}$-cells into Th17 cells [58]. Dectin-1 mediated induction of IL-22 is crucial for releasing antimicrobial peptides that play an important role in fungal clearance [59]. Deficiency in dectin-1 is associated with a defective Th17 response, and therefore impaired neutrophil recruitment and excessive fungal growth $[56,58]$. On the one hand, the Th17 response is activated by stimulation of dectin- 1 with $\beta$-glucans, whereas on the other hand, galactosaminogalactan (GAG) can inhibit Th17 responses in vitro and in vivo, via induction of IL-1Ra [60]. By diminishing the Th17 response, GAG was able to decrease neutrophil recruitment, thereby increasing susceptibility of WT mice to invasive aspergillosis [60,61]. Additional evidence for the importance of the Th17 response in host defense against Aspergillus-infection is provided by the observation that patients with Aspergillus skull base osteomyelitis have defects in Th17 responses [62]. PBMC from patients with chronic granulomatous disease exhibited a lower IL-17A production upon stimulation with Aspergillus and Candida compared to healthy donors, and this might contribute to ineffective fungal clearance in these patients [63]. 
Despite the important role of Th17 for fungal clearance, uncontrolled or prolonged Th17 activation is detrimental to the host, by causing pulmonary damage and persistent inflammation $[64,65]$. Increased Th17 responses are attributed to severe immunopathology characterized by massive neutrophil infiltrates in the lung parenchyma and impairment of fungal clearance [66]. The importance of IL-23 in maintaining the Th17 response is highlighted by the lack of IL-17 producing cells in IL-23p19 -/- mice; whereas in mice with pulmonary aspergillosis, the absence of IL-12 leads to enhanced IL-23 production and increased susceptibility to A. fumigatus. Neutralization of IL-23 and IL-17 can enhance antifungal resistance and decrease fungal burden in models of aspergillosis with detrimental immunopathology [66]. Furthermore, impairment of the IFN $\gamma$ response is associated with increased interleukin-17a expression and attributes to mortality in mice with invasive aspergillosis [67]. The Th17 response is also partially dependent on Toll IL-R8 (TIR8)/single Ig IL-1-related receptor, a member of the IL-1R family which negatively regulates IL-1R signaling. Tir8 ${ }^{-/}$mice were more susceptible to infection and exhibited a higher inflammatory pathology; this finding highlighted the possible role of TIR8 in orchestrating protective response or immunopathology against fungal infection [68]. In vitro stimulation of circulating T-cells demonstrates a preference towards an induction of a Th1 profile [43,69], however, lung derived T-cells isolated from COPD patients were found to have a preference to a Th17 phenotype [69]. Interestingly, the capacity to induce pulmonary Th17 responses to Aspergillus has also been associated with bacteria colonizing the gut microbiota. The presence of segmented filamentous bacteria can influence the pulmonary adaptive immune response partly by increasing Th17 cells population in the lungs [70]. In contrast to the Th17 response that has beneficial effects, the Th2 response not only suppresses protective immunity but also is the key player in allergic disease associated with Aspergillus.

\section{Th2 Response Drives Allergic Hypersensitivity Reactions to Aspergillus}

The Th2 response is not beneficial for fungal clearance in invasive disease, moreover, a Th2 response mounted towards Aspergillus can lead to allergic disease in relatively healthy individuals and in individuals with underlying pulmonary disease such as asthma and cystic fibrosis. It is increasingly recognized that in a significant group of patients, their severe asthma is associated with fungal exposure [71]. There are estimates that fungal molecules represent approximately $16 \%$ of the known allergens [72,73]. To date, over 150 fungal allergens have been identified [74], with the most numerous found in A. fumigatus [73,75]. The response to these allergens includes a strong Th2 response that leads to the development of Aspergillus-specific IgE, which remains to be a diagnostic marker for severe asthma with fungal sensitization (SAFS) [76,77]. A more severe form of allergic response to Aspergillus is allergic bronchopulmonary aspergillosis (ABPA), which is associated with prolonged fungal exposure and typically occurs in individuals with a hypersensitive immune response, where airway inflammation, eosinophilia, and abundant production of Aspergillus-specific IgE are usually present [78]. This allergic form of aspergillosis occurs in 1-2\% of asthmatic patients and up to $10 \%$ of patients with cystic fibrosis (CF), in the latter it is a major cause of deteriorating lung function and mortality. Bronchoalveolar lavage (BAL) of ABPA patients showed the presence of infiltrates rich in eosinophils, neutrophils, lymphocytes and often fungal hyphae $[78,79]$.

The pathogenesis of these allergic forms of aspergillosis is thought to be mediated predominantly by a hyperactive Th2 response (Figure 2), leading to airway hypersensitivity, IgE production and persistent airway inflammation [45]. The hyper-reactive Th2 response can be observed in the response of Peripheral Blood Mononuclear Cells (PBMCs) of ABPA patients, who demonstrate a disturbed Th2/Th1 ratio upon stimulation with A. fumigatus conidia [80]. This disturbed ration is characterized by elevated IL-5 and IL-13, and a low IFN $\gamma$ response in comparison to non-allergic controls [80]. Similarly, in mouse models, repeated exposure to low doses of conidia primes the development of strong Th2 and Th17 responses, resulting in chronic inflammation resembling ABPA [81]. The repetitive exposure to A. fumigatus increases eosinophil accumulation in the lungs and peripheral blood, airway remodeling, and elevated IgE in different murine ABPA models, which can be attributed 
to increased IL-4 and IL-5 and diminished IL-10 production [82-84]. In addition to the high Th2 response, Th17 responses also significantly contribute to the detrimental inflammatory response observed in Aspergillus related allergy, by stimulating excessive neutrophil recruitment $[81,85,86]$. Especially under pre-existing conditions where the immune response is skewed to a Th2 response such as in allergy, infection with A. fumigatus results in increased Th17 response, which could lead to persistent inflammation and defective fungal clearance [87]. It was recently discovered that the Th17 cytokine IL-17F is also involved in allergic airway inflammation, and this effect is mainly dependent on signaling through IL-17RC [86]. In mouse models with Th2/Th17 eosinophilic and neutrophilic allergic airway inflammation induced by $A$. fumigatus hyphal extract, administration of mesenchymal stromal cells (MSC) was shown to significantly decrease airway hyper-responsiveness, through reduction of Th17-mediated inflammation [88].

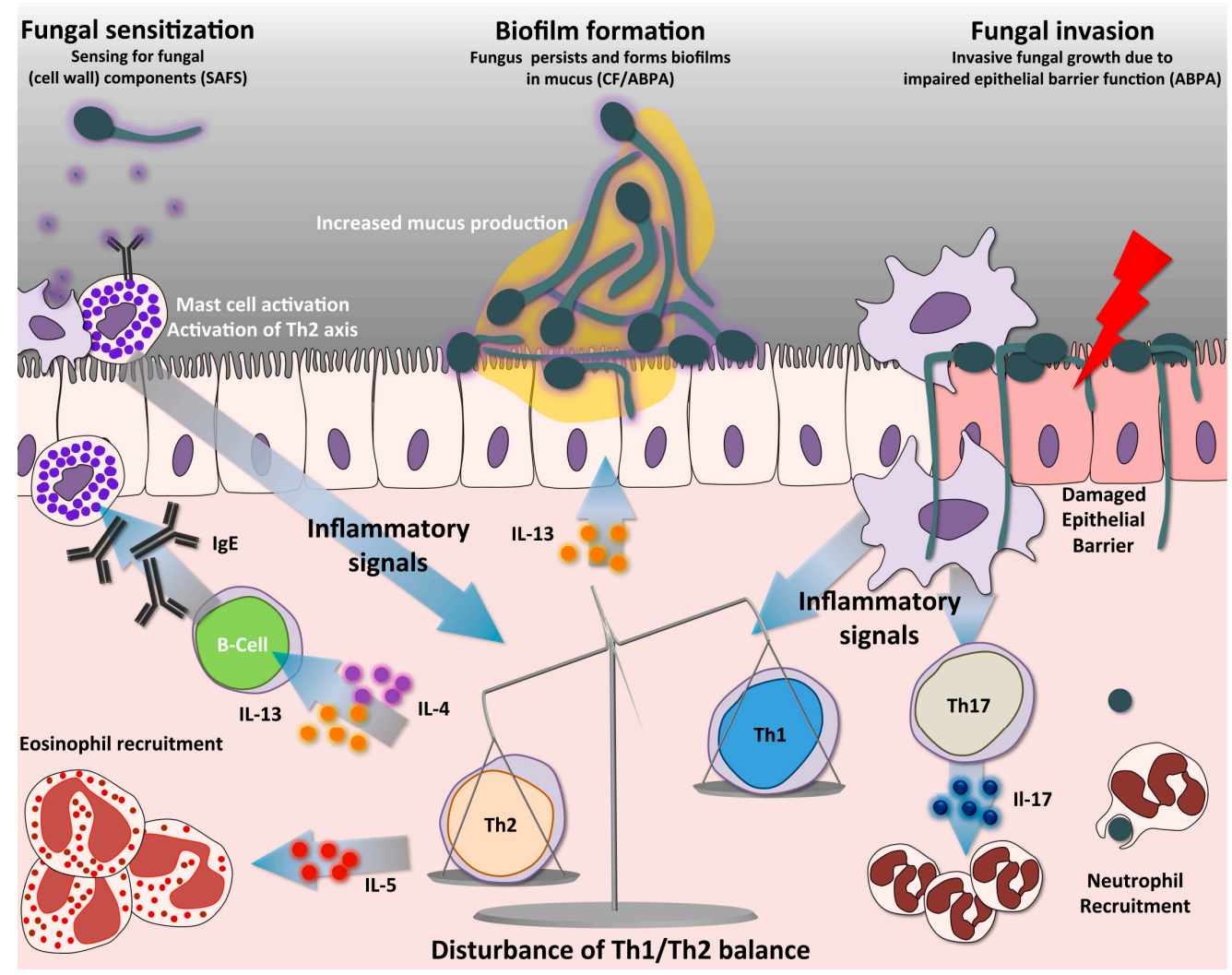

Figure 2. Immune pathways in SAFS and ABPA. Antigen presentation by DCs activates naïve CD4+ T-cells into distinct Th-cell lineages. A predominant non-protective Th2 response is a hallmark in allergic forms of aspergillosis, such as SAFS and ABPA. A distinct characteristic is that the high Th2 response creates an imbalance resulting in low protective Th1 responses. Th2 cells release different cytokines, among them IL-4 and IL-13, which trigger antibody class switching to IgE, a distinct hallmark of SAFS. In addition, these cytokines mediate increased mucus production by respiratory goblet cells, and IL-5, which triggers the recruitment of eosinophils. Abundant mucus production in the airway allows biofilm formation, thus facilitating fungal growth. Furthermore, the absence of fungal clearance leads to continuous airway sensitization with fungal components, activating mast cells and the Th2 axis. Mast cell degranulation releases abundant inflammatory mediators such as histamine and leukotriene, which also contribute to the inflammatory phenotypes of patients. Activation of Th17 cells facilitates recruitment of neutrophils, partly contributing to the persistent immunopathology of these diseases. During ABPA the pulmonary epithelial barrier can become compromised, allowing A. fumigatus to germinate and invade the tissues. SAFS = Severe asthma with fungal sensitization; ABPA = Allergic bronchopulmonary aspergillosis; $\mathrm{CF}=$ Cystic fibrosis. 
The Th9 subset has only recently been described [89], and is closely associated to the Th2 response. Th9 cells are known to mediate inflammation, infection and allergy, and this lineage is differentiated in the presence of Th2-polarizing cytokine IL-4, in combination with IL-2 and TGF $\beta$ [90]. Fully differentiated Th 2 cells cultured with TGF $\beta$ results in increased production of IL-9, which is a signature cytokine of Th9 [90]. In healthy volunteers, the fungal pathogen C. albicans induced IL-9 production, mostly by IL- $9^{+}$IL- $17^{+}$-co-expressing $\mathrm{CD} 4^{+} \mathrm{T}$ cells than IL-9 single positive cells. However in patients with hyper IgE syndrome (HIES) caused by STAT3 mutation, this IL-9 response was significantly lower in the presence of IL-4, which could be due to the deficiency of Th17 cell subset in these patients [91]. The Th9 subset plays a role in the allergic response to A. fumigatus in cystic fibrosis, and blockade of the Th9 response in this setting could represent a novel therapeutic strategy to reduce infection associated inflammation [92].

\section{Regulatory T-Cells}

Regulation of a balanced T-helper response is crucial for resolution of the inflammatory response when infection has been resolved, but also for prevention of detrimental immunopathology during infection or hypersensitivity (Figure 3). Regulatory T-cells are endogenous regulators of inflammatory response, they control inflammation by a variety of mechanisms, for example by contact dependent inhibition of other leukocytes via the surface receptor cytotoxic T-lymphocyte antigen 4 (CTLA-4) or through release of anti-inflammatory cytokines IL-10 and TGF- $\beta$ [93]. Two types of regulatory T-cells (Treg) are known to play a role in the antifungal response against $A$. fumigatus. Natural Treg (nTreg) originate in the thymus and are present in the periphery, providing tolerance in early infection and limiting neutrophil activity, and induced Treg (iTreg) that are primed from naïve CD4 ${ }^{+}$Th cells, and these cells limit inflammation in later stages of infection, preventing fungal allergy by producing IL-10 and TGF $\beta$ [94]. Repeated exposure to aerosolized antigen in mice induces CD4 ${ }^{+}$T-cells expressing both surface and soluble TGF $\beta$, and adoptive transfer of these cells to naïve recipient mice abrogates the allergic phenotype [95].

Similar to the pro-inflammatory T-cell lineages, the Treg [32,34] and Type (1) regulatory T-cells (Tr1) $[34,94]$ cells found during aspergillosis in both humans as well as murine models show Aspergillus-specificity. Type (1) regulatory T-cells (Tr1) are distinct from Treg in their mode of induction, cytokine production and phenotype. Aspergillus-specific $\operatorname{Tr} 1$ are present in peripheral blood of human and mice. Vaccination with Crf1/p41, a cell wall component of the fungus, generated IL-10-producing $\operatorname{Tr} 1$ cells and suppressed antigen-specific T-cell proliferation [34]. Whereas in individuals with allergy to A. fumigatus, despite the presence of Tr1 cells, specific Th2 cells were expanded, indicating the capacity of the fungus to modulate distinct regulatory responses to prevent allergic reactions [32].

In individuals colonized with A. fumigatus that induce a strong Treg response, a high concentration of vitamin D3 in the serum was observed, whereas patients with ABPA that exhibited a predominant Th2 response had a lower vitamin D3 serum concentration [96]. In line with this, vitamin D3 supplementation was found to decrease A. fumigatus-specific Th2 responses in cystic fibrosis patients [97].

Regulation of Treg function versus immunopathology during aspergillosis was found to be closely associated with tryptophan metabolism. The enzyme Indoleamine 2, 3-dioxygenase (IDO) catalyzes the breakdown of tryptophan to kynurenine and is known to activate Treg responses, whereas the presence of IL-23 and Th17 negatively regulates it [66]. Imbalance of the Th17/Treg axis in certain conditions contributes to the pathogenesis of aspergillosis [98]. In mice with chronic granulomatous disease, lack of reactive oxygen species (ROS) disrupted the metabolism of tryptophan along the kynurenine pathway, leading to excessive production of IL-17, defective Treg function, and hyperinflammation. Supplementation with natural kynurenines were able to reverse this hyperinflammatory response [99]. Early in aspergillosis, $\mathrm{CD} 4^{+} \mathrm{CD} 25^{+}$Treg recruitment is able to control inflammation by neutrophil suppression, mediated by the actions of IL-10 and CTLA-4 on IDO. Furthermore, IFN $\gamma$ levels in this early phase of infection partially condition the subsequent adaptive immune response by inducing 
IDO-dependent tolerogenic DCs, which subsequently activate tolerogenic Treg that produce IL-10 and TGF $\beta$, inhibit Th2 cells, and prevent fungal allergy [94]. IDO activation could also be activated in a TLR3/TRIF dependent manner in epithelial cells, resulting in protection against Aspergillus. Mice defective in this pathway exhibited a stronger Th17 response manifested by infiltration of neutrophils in the lungs, decreased Th1/Treg response, and higher fungal burden and immunopathology [20].

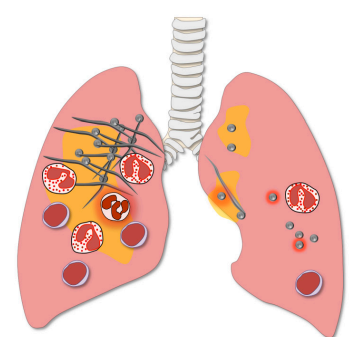

ABPA CF SAFS

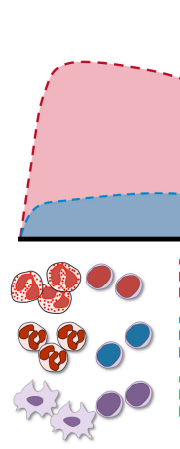

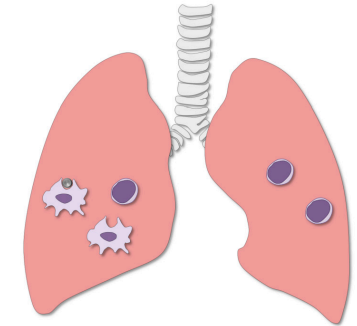

healthy individuals

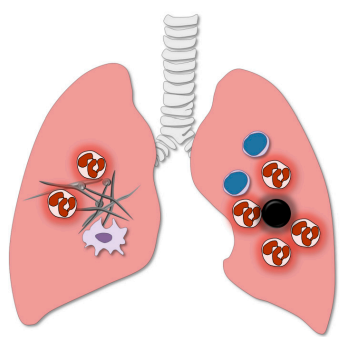

IA

CPA

Figure 3. The role of regulatory T-cells in aspergillosis. Regulatory T-cells (Treg) orchestrate the balance of the Th1, Th2 and Th17 response; and this fine-tuning is necessary for effective fungal clearance in the host. In healthy individuals, the protective Th1 response effectively aids the clearance of $A$. fumigatus, whereas potential damaging excessive Th17 activation is dampened by Treg. A predominant Th2 response in allergic forms of aspergillosis such as SAFS and ABPA, leads to persistent inflammation and fungal colonization. In immunocompromised individuals, failure of innate immune cells to eliminate fungi may cause invasive aspergillosis (IA). When the Th17 response is too potently induced this might lead to excessive neutrophil influx and collateral damage. Fine-tuning of the strong pro-inflammatory responses during aspergillosis is facilitated by Treg, which in turn suppress the Th17/Th2 activity and prevent damage to the host.

\section{Immunotherapy: Optimizing the Potential of T-Helper Responses}

Despite the development of strict antifungal treatment regimens, the mortality and morbidity due to aspergillosis remained relatively unchanged within the past few years [7,100]. Antifungal resistance and a persistent dysregulated immune response in patients with aspergillosis limits the efficacy of antifungal medication [101]. The immunological state of the host remains an important determinant in the outcome of infection, with the absence of efficient innate immune responses predisposing for invasive infection and the induction of hyper-inflammatory responses contributing to immunopathology. Therefore, restoration of dysregulated immune responses, by using immune-based therapies, is believed to be a promising strategy to improve the clinical outcome of fungal infections [102]. Numerous immunomodulatory therapies in pre-clinical experimental phase are aimed at distinct processes of the host-pathogen interactions [103-108]. It should be noted that most immunomodulatory strategies are aimed at boosting the adaptive immune response or at making use of the protective mechanisms provided by the adaptive immune response.

As previously discussed, a robust Th1 response is crucial for efficient clearance of A. fumigatus $[36,40,43]$. To simulate a robust Th1 response, patients can be administered IFN $\gamma$, the 
signature Th1 cytokine. Administration of IFN $\gamma$ was shown to have the potential to augment the host response to control infection against $A$. fumigatus in immunocompromised individuals and CGD patients, improving outcome and reducing mortality $[106,107,109]$. Adjunctive therapy of GM-CSF and IFN $\gamma$ alongside antifungal treatment was also able to improve disease outcome in both neutropenic and non-neutropenic patients $[105,110,111]$.

In contrast to strategies aiming at augmenting the host response, cytokine-based immunotherapies can also be employed to prevent detrimental immunopathology. The Th2/Th1 imbalance observed in ABPA patients could be restored in vitro using IFN $\gamma$ [81], suggesting that IFN $\gamma$ therapy could be a promising strategy to skew the immune responses in ABPA and fungal allergy. Interference of the IL-1 pathway has been an interesting subject in recent years. Inflammasome-dependent IL-1 $\beta$ production is the driving force for Th17 induction, and in certain condition such as cystic fibrosis and CGD this Th17 response can lead to exaggerated tissue damage in the host. Administration of recombinant IL-1 receptor antagonist (IL-1Ra) decreases immunopathology and contribute to a better outcome in Th17-mediated inflammation as a result of Aspergillus-infection in a murine cystic fibrosis model [112] and in a murine CGD model [113]. In corticosteroid immunosuppressed mice, detrimental damage leading to pulmonary tissue hypoxia could be reduced by IL-1Ra [114].

In immunocompromised individuals, such as those undergoing transplantation, cellular immunity is abrogated. Innate immune cell counts subsequently recover, however, lymphocyte numbers remain low for several months, which renders these patients susceptible to infections [115]. Adoptive transfer of in vitro-generated $\mathrm{CD}^{+} \mathrm{T}$-cells in patients receiving allogeneic HSCT has been shown to improve clearance of Aspergillus infection and confer protection against invasive aspergillosis [104,116]. Clinical-scale generation of anti-Aspergillus T-cells can be achieved by stimulating T-cells with a single antigenic epitope, however, whole fungal extract generates T-cells with more efficient anti-fungal properties [116,117]. In addition to expanding normal T-cells, T-cells can also be engineered to have an improved antifungal capacity. Genetic modification of T-cells to express a chimeric antigen receptor (CAR) leads to a redirected signaling after recognition of antigens. By generating a T-cell that expresses dectin- 1 that activates CD28 and CD3 (referred as D-CAR), a T-cell can directly recognize the fungus and induce its anti-fungal effect [118]. Adaptation of other types of receptors specific for A. fumigatus and further validation both in vitro and in vivo is necessary to improve the optimization and application of this promising treatment.

Although there are a growing number of experimental strategies to augment the antifungal host response by targeting T-helper responses, it should be considered that treating disease in immunocompromised patients is more challenging than experimental models, since these individuals have more complex clinical settings. Therefore, the added value of various immunotherapeutic approaches needs to be evaluated on a patient-to-patient basis. The host defense in different patients can be altered in different ways, and different underlying diseases can potentially complicate treatment. Therefore, immunotherapy requires a tailored and personalized approach, taking into account the complexity of different cases and underlying diseases. Well-targeted clinical trials with the right patients and controls aiming at applying these therapies in clinical settings are required to realize immunotherapy for Aspergillus-related diseases in the near future.

\section{Future Perspectives}

Most of the knowledge on T-helper responses in aspergillosis is derived from murine models. Although experimental infection models provide invaluable information on pathogenesis of aspergillosis and the role of T-helper responses, such models cannot always be inferred to humans due to differences in human and murine physiology and host defense. In addition, murine models may not always be representative for patients with aspergillosis, who present with a complex clinical background, can have various underlying diseases and host defense can be altered in multiple and interacting ways. We therefore believe that an important future direction of research should include the evaluation of T-helper responses to Aspergillus in humans in general and preferably in patients with 
aspergillosis specifically. In this way, findings from murine models can be validated and translated to patient settings, and a detailed overview of the human T-helper responses against $A$. fumigatus can be elaborated.

Although T-helper responses are usually described as specific cell subsets, recent studies have demonstrated that in fact there is overlap between the different T-cell subsets [113-122]. Th17 cells co-expressing IFN $\gamma$ or IL-10 have been found in response to the fungal pathogen Candida albicans [121]. However limited numbers of IL-17/IFN $\gamma$ co-expressing cells were observed to be induced by Aspergillus in human PBMCs [122]. IL-22, however, was found to be produced not only by Th17 cells, but also in a T-cell subset co-expressing IFN $\gamma$ and in T-cells exclusively expressing IL-22 [122]. Another discovery that complicates our understanding of the T-helper responses is that regulatory T-cells can co-express IL-17 and potentially contribute to detrimental immunopathology [119]. Recent studies have demonstrated that $A$. fumigatus also induces regulatory T-cells with a Th17-like phenotype [120], however, it remains to be determined to what extent these cells contribute to the detrimental immunopathology seen during aspergillosis. The observation that the expression of lineage-defining cytokines showed a great plasticity among Aspergillus-activated T-cells complicates our understanding of the mechanisms going on in vivo during infection. Increased knowledge and understanding of this plasticity of the T-cell response might in the future lead to strategies that are aimed at utilizing this plasticity to shape T-cell responses in a way for optimal fungal clearance and limited immunopathology. The administration of recombinant cytokines and adoptive transfer of pathogen-specific T cells are several examples of potential successful approaches that have been developed in the past few years. Fundamental studies regarding the therapeutic potential of T-cell plasticity in aspergillosis and clinical trials aiming at applying these therapies in clinical settings are required to realize immunotherapy for Aspergillus-related diseases in the near future.

Acknowledgments: Intan M. W. Dewi is supported by the Indonesian Endowment Fund for Education (LPDP) from the Ministry of Finance, Republic of Indonesia.

Author Contributions: Intan M. W. Dewi and Mark S. Gresnigt performed a thorough revision of the available literature, Intan M. W. Dewi wrote the first draft of the manuscript, Mark S. Gresnigt made the figures and Intan M. W. Dewi, Frank L. van de Veerdonk and Mark S. Gresnigt wrote the paper and approved the final version.

Conflicts of Interest: The authors declare no conflict of interest.

\section{References}

1. Gavalda, J.; Len, O.; San Juan, R.; Aguado, J.M.; Fortun, J.; Lumbreras, C.; Moreno, A.; Munoz, P.; Blanes, M.; Ramos, A.; et al. Risk factors for invasive aspergillosis in solid-organ transplant recipients: A case-control study. Clin. Infect. Dis. 2005, 41, 52-59. [CrossRef] [PubMed]

2. Fishman, J.A. Infection in solid-organ transplant recipients. N. Engl. J. Med. 2007, 357, 2601-2614. [CrossRef] [PubMed]

3. Stuehler, C.; Kuenzli, E.; Jaeger, V.K.; Baettig, V.; Ferracin, F.; Rajacic, Z.; Kaiser, D.; Bernardini, C.; Forrer, P.; Weisser, M.; et al. Immune reconstitution after allogeneic hematopoietic stem cell transplantation and association with occurrence and outcome of invasive aspergillosis. J. Infect. Dis. 2015, 212, 959-967. [CrossRef] [PubMed]

4. Lionakis, M.S.; Kontoyiannis, D.P. Glucocorticoids and invasive fungal infections. Lancet 2003, 362, $1828-1838$. [CrossRef]

5. Todeschini, G.; Murari, C.; Bonesi, R.; Pizzolo, G.; Verlato, G.; Tecchio, C.; Meneghini, V.; Franchini, M.; Giuffrida, C.; Perona, G.; et al. Invasive aspergillosis in neutropenic patients: Rapid neutrophil recovery is a risk factor for severe pulmonary complications. Eur. J. Clin. Investig. 1999, 29, 453-457. [CrossRef]

6. Marr, K.A.; Carter, R.A.; Boeckh, M.; Martin, P.; Corey, L. Invasive aspergillosis in allogeneic stem cell transplant recipients: Changes in epidemiology and risk factors. Blood 2002, 100, 4358-4366. [CrossRef] [PubMed] 
7. Bonnet, S.; Dulery, R.; Regany, K.; Bouketouche, M.; Magro, L.; Coiteux, V.; Alfandari, S.; Berthon, C.; Quesnel, B.; Yakoub-Agha, I. Long-term follow up of invasive aspergillosis in allogeneic stem cell transplantation recipients and leukemia patients: Differences in risk factors and outcomes. Curr. Res. Transl. Med. 2017, 65, 77-81. [CrossRef] [PubMed]

8. Gresnigt, M.S.; Netea, M.G.; van de Veerdonk, F.L. Pattern recognition receptors and their role in invasive aspergillosis. Ann. N. Y. Acad. Sci. 2012, 1273, 60-67. [CrossRef] [PubMed]

9. Camargo, J.F.; Husain, S. Immune correlates of protection in human invasive aspergillosis. Clin. Infect. Dis. Off. Publ. Infect. Dis. Soc. Am. 2014, 59, 569-577. [CrossRef] [PubMed]

10. Espinosa, V.; Rivera, A. First line of defense: Innate cell-mediated control of pulmonary aspergillosis. Front. Microbiol. 2016, 7, 272. [CrossRef] [PubMed]

11. Heinekamp, T.; Schmidt, H.; Lapp, K.; Pahtz, V.; Shopova, I.; Koster-Eiserfunke, N.; Kruger, T.; Kniemeyer, O.; Brakhage, A.A. Interference of Aspergillus fumigatus with the immune response. Semin. Immunopathol. 2015, 37, 141-152. [CrossRef] [PubMed]

12. Hohl, T.M.; Feldmesser, M. Aspergillus fumigatus: Principles of pathogenesis and host defense. Eukaryot. Cell 2007, 6, 1953-1963. [CrossRef] [PubMed]

13. Morton, C.O.; Bouzani, M.; Loeffler, J.; Rogers, T.R. Direct interaction studies between Aspergillus fumigatus and human immune cells; what have we learned about pathogenicity and host immunity? Front. Microbiol. 2012, 3, 413. [CrossRef] [PubMed]

14. Garth, J.M.; Steele, C. Innate lung defense during invasive aspergillosis: New mechanisms. J. Innate Immun. 2017, 9, 271-280. [CrossRef] [PubMed]

15. Chen, K.; Kolls, J.K. T cell-mediated host immune defenses in the lung. Annu. Rev. Immunol. 2013, 31, 605-633. [CrossRef] [PubMed]

16. Romani, L. Immunity to fungal infections. Nat. Rev. Immunol. 2004, 4, 1-23. [CrossRef] [PubMed]

17. Osherov, N. Interaction of the pathogenic mold Aspergillus fumigatus with lung epithelial cells. Front. Microbiol. 2012, 3, 346. [CrossRef] [PubMed]

18. Saenz, S.A.; Taylor, B.C.; Artis, D. Welcome to the neighborhood: Epithelial cell-derived cytokines license innate and adaptive immune responses at mucosal sites. Immunol. Rev. 2008, 226, 172-190. [CrossRef] [PubMed]

19. Mulligan, J.K.; Mulligan, R.M.; Atkinson, C.; Schlosser, R.J. Human sinonasal epithelial cells direct dendritic function and T-cell T helper 1/T helper 2 skewing following aspergillus exposure. Int. Forum. Allergy Rhinol. 2011, 1, 268-274. [CrossRef] [PubMed]

20. De Luca, A.; Bozza, S.; Zelante, T.; Zagarella, S.; D’Angelo, C.; Perruccio, K.; Vacca, C.; Carvalho, A.; Cunha, C.; Aversa, F.; et al. Non-hematopoietic cells contribute to protective tolerance to Aspergillus fumigatus via a trif pathway converging on ido. Cell. Mol. Immunol. 2010, 7, 459-470. [CrossRef] [PubMed]

21. Steele, C.; Rapaka, R.R.; Metz, A.; Pop, S.M.; Williams, D.L.; Gordon, S.; Kolls, J.K.; Brown, G.D. The beta-glucan receptor dectin-1 recognizes specific morphologies of Aspergillus fumigatus. PLoS Pathog. 2005, 1, e42. [CrossRef] [PubMed]

22. Hohl, T.M.; Rivera, A.; Lipuma, L.; Gallegos, A.; Shi, C.; Mack, M.; Pamer, E.G. Inflammatory monocytes facilitate adaptive CD4 T cell responses during respiratory fungal infection. Cell Host Microbe 2009, 6, 470-481. [CrossRef] [PubMed]

23. Ramirez-Ortiz, Z.G.; Means, T.K. The role of dendritic cells in the innate recognition of pathogenic fungi (A. fumigatus, C. neoformans and C. albicans). Virulence 2012, 3, 635-646. [CrossRef] [PubMed]

24. Bozza, S.; Gaziano, R.; Spreca, A.; Bacci, A.; Montagnoli, C.; di Francesco, P.; Romani, L. Dendritic cells transport conidia and hyphae of Aspergillus fumigatus from the airways to the draining lymph nodes and initiate disparate th responses to the fungus. J. Immunol. 2002, 168, 1362-1371. [CrossRef] [PubMed]

25. Gafa, V.; Remoli, M.E.; Giacomini, E.; Gagliardi, M.C.; Lande, R.; Severa, M.; Grillot, R.; Coccia, E.M. In vitro infection of human dendritic cells by Aspergillus fumigatus conidia triggers the secretion of chemokines for neutrophil and Th1 lymphocyte recruitment. Microbes Infect. Inst. Pasteur 2007, 9, 971-980. [CrossRef] [PubMed]

26. Barrios, C.S.; Johnson, B.D.; Henderson, J.D.; Fink, J.N.; Kelly, K.J.; Kurup, V.P. The costimulatory molecules CD80, CD86 and OX401 are up-regulated in Aspergillus fumigatus sensitized mice. Clin. Exp. Immunol. 2005, 142, 242-250. [CrossRef] [PubMed] 
27. Gafa, V.; Lande, R.; Gagliardi, M.C.; Severa, M.; Giacomini, E.; Remoli, M.E.; Nisini, R.; Ramoni, C.; Di Francesco, P.; Aldebert, D. Human dendritic cells following Aspergillus fumigatus infection express the CCR7 receptor and a differential pattern of interleukin-12 (IL-12), IL-23, and IL-27 cytokines, which lead to a th1 response. Infect. Immun. 2006, 74, 1480-1489. [CrossRef] [PubMed]

28. Lother, J.; Breitschopf, T.; Krappmann, S.; Morton, C.O.; Bouzani, M.; Kurzai, O.; Gunzer, M.; Hasenberg, M.; Einsele, H.; Loeffler, J. Human dendritic cell subsets display distinct interactions with the pathogenic mould Aspergillus fumigatus. Int. J. Med. Microbiol. 2014, 304, 1160-1168. [CrossRef] [PubMed]

29. Bozza, S.; Clavaud, C.; Giovannini, G.; Fontaine, T.; Beauvais, A.; Sarfati, J.; D'Angelo, C.; Perruccio, K.; Bonifazi, P.; Zagarella, S.; et al. Immune sensing of Aspergillus fumigatus proteins, glycolipids, and polysaccharides and the impact on th immunity and vaccination. J. Immunol. 2009, 183, 2407-2414. [CrossRef] [PubMed]

30. Fei, M.; Bhatia, S.; Oriss, T.B.; Yarlagadda, M.; Khare, A.; Akira, S.; Saijo, S.; Iwakura, Y.; Fallert Junecko, B.A.; Reinhart, T.A.; et al. TNF- $\alpha$ from inflammatory dendritic cells (DCS) regulates lung IL-17a/IL-5 levels and neutrophilia versus eosinophilia during persistent fungal infection. Proc. Natl. Acad. Sci. USA 2011, 108, 5360-5365. [CrossRef] [PubMed]

31. Chamilos, G.; Ganguly, D.; Lande, R.; Gregorio, J.; Meller, S.; Goldman, W.E.; Gilliet, M.; Kontoyiannis, D.P. Generation of IL-23 producing dendritic cells (DCS) by airborne fungi regulates fungal pathogenicity via the induction of Th-17 responses. PLoS ONE 2010, 5, e12955. [CrossRef] [PubMed]

32. Bacher, P.; Kniemeyer, O.; Schonbrunn, A.; Sawitzki, B.; Assenmacher, M.; Rietschel, E.; Steinbach, A.; Cornely, O.A.; Brakhage, A.A.; Thiel, A.; et al. Antigen-specific expansion of human regulatory T cells as a major tolerance mechanism against mucosal fungi. Mucosal Immunol. 2014, 7, 916-928. [CrossRef] [PubMed]

33. Jolink, H.; Hagedoorn, R.S.; Lagendijk, E.L.; Drijfhout, J.W.; van Dissel, J.T.; Falkenburg, J.H.F.; Heemskerk, M.H.M. Induction of a. Fumigatus-specific CD4-positive T cells in patients recovering from invasive aspergillosis. Haematologica 2014, 99, 1255-1263. [CrossRef] [PubMed]

34. Bedke, T.; Iannitti, R.G.; De Luca, A.; Giovannini, G.; Fallarino, F.; Berges, C.; Latge, J.P.; Einsele, H.; Romani, L.; Topp, M.S. Distinct and complementary roles for Aspergillus fumigatus-specific TR1 and FOXP3+ regulatory t cells in humans and mice. Immunol. Cell Biol. 2014, 92, 659-670. [CrossRef] [PubMed]

35. Cenci, E.; Mencacci, A.; Bacci, A.; Bistoni, F.; Kurup, V.P.; Romani, L. T cell vaccination in mice with invasive pulmonary aspergillosis. J. Immunol. (Baltimore, MD) 2000, 165, 381-388. [CrossRef]

36. Cenci, E.; Mencacci, A.; Fè d’Ostiani, C.; Del Sero, G.; Mosci, P.; Montagnoli, C.; Bacci, A.; Romani, L. Cytokine- and $\mathrm{T}$ helper-dependent lung mucosal immunity in mice with invasive pulmonary aspergillosis. J. Infect. Dis. 1998, 178, 1750-1760. [CrossRef] [PubMed]

37. Cenci, E.; Mencacci, A.; DelSero, G.; Bistoni, F.; Romani, L. Induction of protective th1 responses to candida albicans by antifungal therapy alone or in combination with an interleukin-4 antagonist. J. Infect. Dis. 1997, 176, 217-226. [CrossRef] [PubMed]

38. Cenci, E.; Perito, S.; Enssle, K.H.; Mosci, P.; Latge, J.P.; Romani, L.; Bistoni, F. Th1 and th2 cytokines in mice with invasive aspergillosis. Infect. Immun. 1997, 65, 564-570. [PubMed]

39. Romani, L.; Bistoni, F.; Gaziano, R.; Bozza, S.; Montagnoli, C.; Perruccio, K.; Pitzurra, L.; Bellocchio, S.; Velardi, A.; Rasi, G.; et al. Thymosin alpha 1 activates dendritic cells for antifungal Th1 resistance through toll-like receptor signaling. Blood 2004, 103, 4232-4239. [CrossRef] [PubMed]

40. Brieland, J.K.; Jackson, C.; Menzel, F.; Loebenberg, D.; Cacciapuoti, A.; Halpern, J.; Hurst, S.; Muchamuel, T.; Debets, R.; Kastelein, R.; et al. Cytokine networking in lungs of immunocompetent mice in response to inhaled Aspergillus fumigatus. Infect. Immun. 2001, 69, 1554-1560. [CrossRef] [PubMed]

41. Damsker, J.M.; Hansen, A.M.; Caspi, R.R. Th1 and th17 cells: Adversaries and collaborators. Ann. N. Y. Acad. Sci. 2010, 1183, 211-221. [CrossRef] [PubMed]

42. Antachopoulos, C.; Roilides, E. Cytokines and fungal infections. Br. J. Haematol. 2005, 129, 583-596. [CrossRef] [PubMed]

43. Chai, L.Y.; Van De Veerdonk, F.; Marijnissen, R.J.; Cheng, S.C.; Khoo, A.L.; Hectors, M.; Lagrou, K.; Vonk, A.G.; Maertens, J.; Joosten, L.A. Anti-aspergillus human host defence relies on type $1 \mathrm{~T}$ helper (th1), rather than type 17 T helper (Th17), cellular immunity. Immunology 2010, 130, 46-54. [CrossRef] [PubMed]

44. Nagai, H.; Guo, J.; Choi, H.; Kurup, V. Interferon- $\gamma$ and tumor necrosis factor- $\alpha$ protect mice from invasive aspergillosis. J. Infect. Dis. 1995, 172, 1554-1560. [CrossRef] [PubMed] 
45. Moss, R.B. Pathophysiology and immunology of allergic bronchopulmonary aspergillosis. Med. Mycol. 2005, 43, 203-206. [CrossRef]

46. Cenci, E.; Mencacci, A.; Del Sero, G.; Bacci, A.; Montagnoli, C.; Fè d'Ostiani, C.; Mosci, P.; Bachmann, M.; Bistoni, F.; Kopf, M.; et al. Interleukin-4 causes susceptibility to invasive pulmonary aspergillosis through suppression of protective type i responses. J. Infect. Dis. 1999, 180, 1957-1968. [CrossRef] [PubMed]

47. Del Sero, G.; Mencacci, A.; Cenci, E.; d'Ostiani, C.F.; Montagnoli, C.; Bacci, A.; Mosci, P.; Kopf, M.; Romani, L. Antifungal type 1 responses are upregulated in IL-10-deficient mice. Microbes Infect. Inst. Pasteur 1999, 1, 1169-1180. [CrossRef]

48. Homma, T.; Kato, A.; Bhushan, B.; Norton, J.E.; Suh, L.A.; Carter, R.G.; Gupta, D.S.; Schleimer, R.P. Role of Aspergillus fumigatus in triggering protease-activated receptor-2 in airway epithelial cells and skewing the cells toward a T-helper 2 bias. Am. J. Respir. Cell Mol. Biol. 2016, 54, 60-70. [CrossRef] [PubMed]

49. Croston, T.L.; Nayak, A.P.; Lemons, A.R.; Goldsmith, W.T.; Gu, J.K.; Germolec, D.R.; Beezhold, D.H.; Green, B.J. Influence of Aspergillus fumigatus conidia viability on murine pulmonary microrna and mRNA expression following subchronic inhalation exposure. Clin. Exp. Allergy J. Br. Soc. Allergy Clin. Immunol. 2016, 46, 1315-1327. [CrossRef] [PubMed]

50. Castanhinha, S.; Sherburn, R.; Walker, S.; Gupta, A.; Bossley, C.J.; Buckley, J.; Ullmann, N.; Grychtol, R.; Campbell, G.; Maglione, M.; et al. Pediatric severe asthma with fungal sensitization is mediated by steroid-resistant il-33. J. Allergy Clin. Immunol. 2015, 136, 312-322. [CrossRef] [PubMed]

51. Park, H.; Li, Z.; Yang, X.O.; Chang, S.H.; Nurieva, R.; Wang, Y.H.; Wang, Y.; Hood, L.; Zhu, Z.; Tian, Q.; et al. A distinct lineage of CD4 T cells regulates tissue inflammation by producing interleukin 17. Nat. Immunol. 2005, 6, 1133-1141. [CrossRef] [PubMed]

52. Ghoreschi, K.; Laurence, A.; Yang, X.P.; Tato, C.M.; McGeachy, M.J.; Konkel, J.E.; Ramos, H.L.; Wei, L.; Davidson, T.S.; Bouladoux, N.; et al. Generation of pathogenic Th17 cells in the absence of TGF-beta signalling. Nature 2010, 467, 967-971. [CrossRef] [PubMed]

53. Gresnigt, M.S.; Rosler, B.; Jacobs, C.W.; Becker, K.L.; Joosten, L.A.; van der Meer, J.W.; Netea, M.G.; Dinarello, C.A.; van de Veerdonk, F.L. The IL-36 receptor pathway regulates Aspergillus fumigatus-induced Th1 and Th17 responses. Eur. J. Immunol. 2013, 43, 416-426. [CrossRef] [PubMed]

54. van de Veerdonk, F.L.; Gresnigt, M.S.; Kullberg, B.J.; van der Meer, J.W.; Joosten, L.A.; Netea, M.G. Th17 responses and host defense against microorganisms: An overview. BMB Rep. 2009, 42, 776-787. [CrossRef] [PubMed]

55. Way, E.E.; Chen, K.; Kolls, J.K. Dysregulation in lung immunity-The protective and pathologic Th17 response in infection. Eur. J. Immunol. 2013, 43, 3116-3124. [CrossRef] [PubMed]

56. Werner, J.L.; Metz, A.E.; Horn, D.; Schoeb, T.R.; Hewitt, M.M.; Schwiebert, L.M.; Faro-Trindade, I.; Brown, G.D.; Steele, C. Requisite role for the dectin-1 $\beta$-glucan receptor in pulmonary defense against Aspergillus fumigatus. J. Immunol. 2009, 182, 4938-4946. [CrossRef] [PubMed]

57. Dudakov, J.A.; Hanash, A.M.; van den Brink, M.R.M. Interleukin-22: Immunobiology and pathology. Annu. Rev. Immunol. 2015, 33, 747-785. [CrossRef] [PubMed]

58. Rivera, A.; Hohl, T.M.; Collins, N.; Leiner, I.; Gallegos, A.; Saijo, S.; Coward, J.W.; Iwakura, Y.; Pamer, E.G. Dectin-1 diversifies Aspergillus fumigatus-specific t cell responses by inhibiting T helper type 1 CD4 T cell differentiation. J. Exp. Med. 2011, 208, 369-381. [CrossRef] [PubMed]

59. Gessner, M.A.; Werner, J.L.; Lilly, L.M.; Nelson, M.P.; Metz, A.E.; Dunaway, C.W.; Chan, Y.R.; Ouyang, W.; Brown, G.D.; Weaver, C.T.; et al. Dectin-1-dependent interleukin-22 contributes to early innate lung defense against Aspergillus fumigatus. Infect. Immun. 2012, 80, 410-417. [CrossRef] [PubMed]

60. Gresnigt, M.S.; Bozza, S.; Becker, K.L.; Joosten, L.A.; Abdollahi-Roodsaz, S.; van der Berg, W.B.; Dinarello, C.A.; Netea, M.G.; Fontaine, T.; De Luca, A.; et al. A polysaccharide virulence factor from Aspergillus fumigatus elicits anti-inflammatory effects through induction of interleukin-1 receptor antagonist. PLoS Pathog. 2014, 10, e1003936. [CrossRef] [PubMed]

61. Fontaine, T.; Delangle, A.; Simenel, C.; Coddeville, B.; van Vliet, S.J.; van Kooyk, Y.; Bozza, S.; Moretti, S.; Schwarz, F.; Trichot, C.; et al. Galactosaminogalactan, a new immunosuppressive polysaccharide of Aspergillus fumigatus. PLoS Pathog. 2011, 7, e1002372. [CrossRef] [PubMed]

62. Delsing, C.E.; Becker, K.L.; Simon, A.; Kullberg, B.J.; Bleeker-Rovers, C.P.; van de Veerdonk, F.L.; Netea, M.G. Th17 cytokine deficiency in patients with aspergillus skull base osteomyelitis. BMC Infect. Dis. 2015, 15, 140. [CrossRef] [PubMed] 
63. Smeekens, S.P.; Henriet, S.S.; Gresnigt, M.S.; Joosten, L.A.; Hermans, P.W.; Netea, M.G.; Warris, A.; van de Veerdonk, F.L. Low interleukin-17A production in response to fungal pathogens in patients with chronic granulomatous disease. J. Interferon Cytokine Res. 2012, 32, 159-168. [CrossRef] [PubMed]

64. Zelante, T.; De Luca, A.; D'Angelo, C.; Moretti, S.; Romani, L. IL-17/Th17 in anti-fungal immunity: What's new? Eur. J. Immunol. 2009, 39, 645-648. [CrossRef] [PubMed]

65. Zelante, T.; Bozza, S.; De Luca, A.; D’Angelo, C.; Bonifazi, P.; Moretti, S.; Giovannini, G.; Bistoni, F.; Romani, L. Th17 cells in the setting of aspergillus infection and pathology. Med. Mycol. 2009, 47, S162-S169. [CrossRef] [PubMed]

66. Zelante, T.; De Luca, A.; Bonifazi, P.; Montagnoli, C.; Bozza, S.; Moretti, S.; Belladonna, M.L.; Vacca, C.; Conte, C.; Mosci, P.; et al. IL-23 and the Th17 pathway promote inflammation and impair antifungal immune resistance. Eur. J. Immunol. 2007, 37, 2695-2706. [CrossRef] [PubMed]

67. Armstrong-James, D.P.H.; Turnbull, S.A.; Teo, I.; Stark, J.; Rogers, N.J.; Rogers, T.R.F.; Bignell, E.; Haynes, K. Impaired interferon- $\gamma$ responses, increased interleukin-17 expression, and a tumor necrosis factor- $\alpha$ transcriptional program in invasive aspergillosis. J. Infect. Dis. 2009, 200, 1341-1351. [CrossRef] [PubMed]

68. Bozza, S.; Zelante, T.; Moretti, S.; Bonifazi, P.; DeLuca, A.; D’Angelo, C.; Giovannini, G.; Garlanda, C.; Boon, L.; Bistoni, F.; et al. Lack of toll IL-1R8 exacerbates Th17 cell responses in fungal infection. J. Immunol. 2008, 180, 4022-4031. [CrossRef] [PubMed]

69. Jolink, H.; de Boer, R.; Hombrink, P.; Jonkers, R.E.; van Dissel, J.T.; Falkenburg, J.H.; Heemskerk, M.H. Pulmonary immune responses against Aspergillus fumigatus are characterized by high frequencies of IL-17 producing T-cells. J. Infect. 2017, 74, 81-88. [CrossRef] [PubMed]

70. McAleer, J.P.; Nguyen, N.L.; Chen, K.; Kumar, P.; Ricks, D.M.; Binnie, M.; Armentrout, R.A.; Pociask, D.A.; Hein, A.; Yu, A.; et al. Pulmonary Th17 antifungal immunity is regulated by the gut microbiome. J. Immunol. 2016, 197, 97-107. [CrossRef] [PubMed]

71. Denning, D.W.; O'Driscoll, B.R.; Hogaboam, C.M.; Bowyer, P.; Niven, R.M. The link between fungi and severe asthma: A summary of the evidence. Eur. Respir. J. Off. J. Eur. Soc. Clin. Respir. Physiol. 2006, 27, 615-626. [CrossRef] [PubMed]

72. Radauer, C.; Nandy, A.; Ferreira, F.; Goodman, R.E.; Larsen, J.N.; Lidholm, J.; Pomes, A.; Raulf-Heimsoth, M.; Rozynek, P.; Thomas, W.R.; et al. Update of the who/IUIS allergen nomenclature database based on analysis of allergen sequences. Allergy 2014, 69, 413-419. [CrossRef] [PubMed]

73. Crameri, R.; Garbani, M.; Rhyner, C.; Huitema, C. Fungi: The neglected allergenic sources. Allergy 2014, 69, 176-185. [CrossRef] [PubMed]

74. Simon-Nobbe, B.; Denk, U.; Poll, V.; Rid, R.; Breitenbach, M. The spectrum of fungal allergy. Int. Arch. Allergy Immunol. 2008, 145, 58-86. [CrossRef] [PubMed]

75. Crameri, R. Structural aspects of fungal allergens. Semin. Immunopathol. 2015, 37, 117-121. [CrossRef] [PubMed]

76. Sehgal, I.S.; Agarwal, R. Specific ige is better than skin testing for detecting aspergillus sensitization and allergic bronchopulmonary aspergillosis in asthma. Chest 2015, 147, e194. [CrossRef] [PubMed]

77. De Barros Bezerra, G.F.; Haidar, D.M.C.; da Silva, M.A.C.N.; Filho, W.E.M.; dos Santos, R.M.; Rosa, I.G.; de Castro Viana, G.M.; Zaror, L.; Soares Brandão Nascimento, M.d.D. Ige serum concentration against airborne fungi in children with respiratory allergies. Allergy Asthma Clin. Immunol. Off. J. Can. Soc. Allergy Clin. Immunol. 2016, 12, 18. [CrossRef] [PubMed]

78. Agarwal, R.; Chakrabarti, A.; Shah, A.; Gupta, D.; Meis, J.F.; Guleria, R.; Moss, R.; Denning, D.W. Allergic bronchopulmonary aspergillosis: Review of literature and proposal of new diagnostic and classification criteria. Clin. Exp. Allergy J. Br. Soc. Allergy Clin. Immunol. 2013, 43, 850-873. [CrossRef] [PubMed]

79. Wark, P.A.B.; Gibson, P.G. Allergic bronchopulmonary aspergillosis: New concepts of pathogenesis and treatment. Respirology 2001, 6, 1-7. [CrossRef] [PubMed]

80. Becker, K.L.; Gresnigt, M.S.; Smeekens, S.P.; Jacobs, C.W.; Magis-Escurra, C.; Jaeger, M.; Wang, X.; Lubbers, R.; Oosting, M.; Joosten, L.A.B.; et al. Pattern recognition pathways leading to a Th2 cytokine bias in allergic bronchopulmonary aspergillosis patients. Clin. Exp. Allergy 2015, 45, 423-437. [CrossRef] [PubMed]

81. Murdock, B.J.; Shreiner, A.B.; McDonald, R.A.; Osterholzer, J.J.; White, E.S.; Toews, G.B.; Huffnagle, G.B. Coevolution of Th1, Th2, and Th17 responses during repeated pulmonary exposure to Aspergillus fumigatus conidia. Infect. Immun. 2011, 79, 125-135. [CrossRef] [PubMed] 
82. Kurup, V.P.; Choi, H.; Murali, P.S.; Coffman, R.L. IgE and eosinophil regulation in a murine model of allergic aspergillosis. J. Leukoc. Biol. 1994, 56, 593-598. [PubMed]

83. Grünig, G.; Corry, D.B.; Leach, M.W.; Seymour, B.W.P.; Kurup, V.P.; Rennick, D.M. Interleukin-10 is a natural suppressor of cytokine production and inflammation in a murine model of allergic bronchopulmonary aspergillosis. J. Exp. Med. 1997, 185, 1089-1100. [CrossRef] [PubMed]

84. Wang, J.M.; Denis, M.; Fournfer, M.; Laviolette, M. Experimental allergic bronchopulmonary aspergillosis in the mouse: Immunological and histological features. Scand. J. Immunol. 1994, 39, 19-26. [CrossRef] [PubMed]

85. Murdock, B.J.; Falkowski, N.R.; Shreiner, A.B.; Sadighi Akha, A.A.; McDonald, R.A.; White, E.S.; Toews, G.B.; Huffnagle, G.B. Interleukin-17 drives pulmonary eosinophilia following repeated exposure to Aspergillus fumigatus conidia. Infect. Immun. 2012, 80, 1424-1436. [CrossRef] [PubMed]

86. De Luca, A.; Pariano, M.; Cellini, B.; Costantini, C.; Villella, V.R.; Jose, S.S.; Palmieri, M.; Borghi, M.; Galosi, C.; Paolicelli, G.; et al. The IL-17F/IL-17RC axis promotes respiratory allergy in the proximal airways. Cell Rep. 2017, 20, 1667-1680. [CrossRef] [PubMed]

87. Fukahori, S.; Matsuse, H.; Tsuchida, T.; Kawano, T.; Nishino, T.; Fukushima, C.; Kohno, S. Clearance of Aspergillus fumigatus is impaired in the airway in allergic inflammation. Ann. Allergy Asthma Immunol. Off. Publ. Am. Coll. Allergy Asthma Immunol. 2014, 113, 180-186. [CrossRef] [PubMed]

88. Lathrop, M.J.; Brooks, E.M.; Bonenfant, N.R.; Sokocevic, D.; Borg, Z.D.; Goodwin, M.; Loi, R.; Cruz, F.; Dunaway, C.W.; Steele, C.; et al. Mesenchymal stromal cells mediate aspergillus hyphal extract-induced allergic airway inflammation by inhibition of the Th17 signaling pathway. Stem Cells Transl. Med. 2014, 3, 194-205. [CrossRef] [PubMed]

89. Borghi, M.; Renga, G.; Puccetti, M.; Oikonomou, V.; Palmieri, M.; Galosi, C.; Bartoli, A.; Romani, L. Antifungal th immunity: Growing up in family. Front. Immunol. 2014, 5, 506. [CrossRef] [PubMed]

90. Kaplan, M.H.; Hufford, M.M.; Olson, M.R. The development and in vivo function of T helper 9 cells. Nat. Rev. Immunol. 2015, 15, 295-307. [CrossRef] [PubMed]

91. Becker, K.L.; Rösler, B.; Wang, X.; Lachmandas, E.; Kamsteeg, M.; Jacobs, C.W.; Joosten, L.A.; Netea, M.G.; van de Veerdonk, F.L. Th2 and Th9 responses in patients with chronic mucocutaneous candidiasis and hyper-ige syndrome. Clin. Exp. Allergy 2016, 46, 1564-1574. [CrossRef] [PubMed]

92. Moretti, S.; Renga, R.; Oikonomou, V.; Galosi, C.; Pariano, M.; Napolioni, V.; Romani, L. A mast cell-ILC2-Th9 pathway promotes lung inflammation in cystic fibrosis. Nat. Commun. 2017, 8, 14017. [CrossRef] [PubMed]

93. Vignali, D.A.A.; Collison, L.W.; Workman, C.J. How regulatory t cells work. Nat. Rev. Immunol. 2008, 8, 523-532. [CrossRef] [PubMed]

94. Montagnoli, C.; Fallarino, F.; Gaziano, R.; Bozza, S.; Bellocchio, S.; Zelante, T.; Kurup, W.P.; Pitzurra, L.; Puccetti, P.; Romani, L. Immunity and tolerance to aspergillus involve functionally distinct regulatory $t$ cells and tryptophan catabolism. J. Immunol. 2006, 176, 1712-1723. [CrossRef] [PubMed]

95. Ostroukhova, M.; Seguin-Devaux, C.; Oriss, T.B.; Dixon-McCarthy, B.; Yang, L.; Ameredes, B.T.; Corcoran, T.E.; Ray, A. Tolerance induced by inhaled antigen involves CD4(+) T cells expressing membrane-bound TGF-beta and FOXP3. J. Clin. Investig. 2004, 114, 28-38. [CrossRef] [PubMed]

96. Kreindler, J.L.; Steele, C.; Nguyen, N.; Chan, Y.R.; Pilewski, J.M.; Alcorn, J.F.; Vyas, Y.M.; Aujla, S.J.; Finelli, P.; Blanchard, M.; et al. Vitamin d3 attenuates Th2 responses to Aspergillus fumigatus mounted by CD4+ T cells from cystic fibrosis patients with allergic bronchopulmonary aspergillosis. J. Clin. Investig. 2010, 120, 3242-3254. [CrossRef] [PubMed]

97. Nguyen, N.L.; Pilewski, J.M.; Celedon, J.C.; Mandalapu, S.; Blanchard, M.L.; DeRicco, A.; Hartigan, E.; Alcorn, J.F.; Kolls, J.K. Vitamin D supplementation decreases Aspergillus fumigatus specific Th2 responses in CF patients with aspergillus sensitization: A phase one open-label study. Asthma Res. Pract. 2015, 1. [CrossRef] [PubMed]

98. Segal, B.H.; Romani, L.R. Invasive aspergillosis in chronic granulomatous disease. Med. Mycol. 2009, 47, S282-S290. [CrossRef] [PubMed]

99. Romani, L.; Fallarino, F.; De Luca, A.; Montagnoli, C.; D’Angelo, C.; Zelante, T.; Vacca, C.; Bistoni, F.; Fioretti, M.C.; Grohmann, U.; et al. Defective tryptophan catabolism underlies inflammation in mouse chronic granulomatous disease. Nature 2008, 451, 211-215. [CrossRef] [PubMed]

100. Porpon, R.; Chen, Y.C.; Chakrabarti, A.; Li, R.Y.; Shivaprakash, R.M.; Yu, J.; Kung, H.C.; Watcharananan, S.; Tan, A.L.; Saffari, S.E.; et al. Epidemiology and clinical characteristics of invasive mould infections: A multicenter, retrospective analysis in five asian countries. Med. Mycol. 2017. [CrossRef] [PubMed] 
101. Brown, G.D.; Denning, D.W.; Gow, N.A.; Levitz, S.M.; Netea, M.G.; White, T.C. Hidden killers: Human fungal infections. Sci. Transl. Med. 2012, 4, 165rv113. [CrossRef] [PubMed]

102. Armstrong-James, D.; Brown, G.D.; Netea, M.G.; Zelante, T.; Gresnigt, M.S.; van de Veerdonk, F.L.; Levitz, S.M. Immunotherapeutic approaches to treatment of fungal diseases. Lancet Infect. Dis. 2017. [CrossRef]

103. Carvalho, A.; Cunha, C.; Bistoni, F.; Romani, L. Immunotherapy of aspergillosis. Clin. Microbiol. Infect. Off. Publ. Eur. Soc. Clin. Microbiol. Infect. Dis. 2012, 18, 120-125. [CrossRef] [PubMed]

104. Papadopoulou, A.; Kaloyannidis, P.; Yannaki, E.; Cruz, C.R. Adoptive transfer of aspergillus-specific $t$ cells as a novel anti-fungal therapy for hematopoietic stem cell transplant recipients: Progress and challenges. Crit. Rev. Oncol. Hematol. 2016, 98, 62-72. [CrossRef] [PubMed]

105. Safdar, A.; Rodriguez, G.; Zuniga, J.; Al Akhrass, F.; Georgescu, G.; Pande, A. Granulocyte macrophage colony-stimulating factor in 66 patients with myeloid or lymphoid neoplasms and recipients of hematopoietic stem cell transplantation with invasive fungal disease. Acta Haematol. 2013, 129, 26-34. [CrossRef] [PubMed]

106. Armstrong-James, D.; Teo, I.A.; Shrivastava, S.; Petrou, M.A.; Taube, D.; Dorling, A.; Shaunak, S. Exogenous interferon-gamma immunotherapy for invasive fungal infections in kidney transplant patients. Am. J. Transpl. 2010, 10, 1796-1803. [CrossRef] [PubMed]

107. Delsing, C.E.; Gresnigt, M.S.; Leentjens, J.; Preijers, F.; Frager, F.A.; Kox, M.; Monneret, G.; Venet, F.; Bleeker-Rovers, C.P.; van de Veerdonk, F.L.; et al. Interferon-gamma as adjunctive immunotherapy for invasive fungal infections: A case series. BMC Infect. Dis. 2014, 14, 166. [CrossRef] [PubMed]

108. Tramsen, L.; Koehl, U.; Tonn, T.; Latge, J.P.; Schuster, F.R.; Borkhardt, A.; Uharek, L.; Quaritsch, R.; Beck, O.; Seifried, E.; et al. Clinical-scale generation of human anti-aspergillus T cells for adoptive immunotherapy. Bone Marrow Transplant. 2009, 43, 13-19. [CrossRef] [PubMed]

109. Marciano, B.E.; Wesley, R.; De Carlo, E.S.; Anderson, V.L.; Barnhart, L.A.; Darnell, D.; Malech, H.L.; Gallin, J.I.; Holland, S.M. Long-term interferon- $\gamma$ therapy for patients with chronic granulomatous disease. Clin. Infect. Dis. 2004, 39, 692-699. [CrossRef] [PubMed]

110. Wan, L.; Zhang, Y.; Lai, Y.; Jiang, M.; Song, Y.; Zhou, J.; Zhang, Z.; Duan, X.; Fu, Y.; Liao, L.; et al. Effect of granulocyte-macrophage colony-stimulating factor on prevention and treatment of invasive fungal disease in recipients of allogeneic stem-cell transplantation: A prospective multicenter randomized phase iv trial. J. Clin. Oncol. 2015, 33, 3999-4006. [CrossRef] [PubMed]

111. Bandera, A.; Trabattoni, D.; Ferrario, G.; Cesari, M.; Franzetti, F.; Clerici, M.; Gori, A. Interferon- $\gamma$ and granulocyte-macrophage colony stimulating factor therapy in three patients with pulmonary aspergillosis. Infection 2008, 36, 368-373. [CrossRef] [PubMed]

112. Iannitti, R.G.; Napolioni, V.; Oikonomou, V.; De Luca, A.; Galosi, C.; Pariano, M.; Massi-Benedetti, C.; Borghi, M.; Puccetti, M.; Lucidi, V.; et al. IL-1 receptor antagonist ameliorates inflammasome-dependent inflammation in murine and human cystic fibrosis. Nat. Commun. 2016, 7, 10791. [CrossRef] [PubMed]

113. de Luca, A.; Smeekens, S.P.; Casagrande, A.; Iannitti, R.; Conway, K.L.; Gresnigt, M.S.; Begun, J.; Plantinga, T.S.; Joosten, L.A.; van der Meer, J.W.; et al. IL-1 receptor blockade restores autophagy and reduces inflammation in chronic granulomatous disease in mice and in humans. Proc. Natl. Acad. Sci. USA 2014, 111, 3526-3531. [CrossRef] [PubMed]

114. Gresnigt, M.S.; Rekiki, A.; Rasid, O.; Savers, A.; Jouvion, G.; Dannaoui, E.; Parlato, M.; Fitting, C.; Brock, M.; Cavaillon, J.M.; et al. Reducing hypoxia and inflammation during invasive pulmonary aspergillosis by targeting the interleukin-1 receptor. Sci. Rep. 2016, 6, 26490. [CrossRef] [PubMed]

115. Geddes, M.; Storek, J. Immune reconstitution following hematopoietic stem-cell transplantation. Best Pract. Res. Clin. Haematol. 2007, 20, 329-348. [CrossRef] [PubMed]

116. Perruccio, K.; Tosti, A.; Burchielli, E.; Topini, F.; Ruggeri, L.; Carotti, A.; Capanni, M.; Urbani, E.; Mancusi, A.; Aversa, F. Transferring functional immune responses to pathogens after haploidentical hematopoietic transplantation. Blood 2005, 106, 4397-4406. [CrossRef] [PubMed]

117. Lehrnbecher, T.; Schmidt, S.; Tramsen, L.; Klingebiel, T. Immunotherapy of invasive fungal infection in hematopoietic stem cell transplant recipients. Front. Oncol. 2013, 3. [CrossRef] [PubMed]

118. Kumaresan, P.R.; Manuri, P.R.; Albert, N.D.; Maiti, S.; Singh, H.; Mi, T.; Roszik, J.; Rabinovich, B.; Olivares, S.; Krishnamurthy, J.; et al. Bioengineering $\mathrm{t}$ cells to target carbohydrate to treat opportunistic fungal infection. Proc. Natl. Acad. Sci. USA 2014, 111, 10660-10665. [CrossRef] [PubMed] 
119. Koenen, H.J.; Smeets, R.L.; Vink, P.M.; van Rijssen, E.; Boots, A.M.; Joosten, I. Human cd25highfoxp3pos regulatory $t$ cells differentiate into il-17-producing cells. Blood 2008, 112, 2340-2352. [CrossRef] [PubMed]

120. Raijmakers, R.P.H.; Sprenkeler, E.G.G.; Aleva, F.E.; Jacobs, C.W.M.; Kanneganti, T.D.; Joosten, L.A.B.; van de Veerdonk, F.L.; Gresnigt, M.S. Toll-like receptor 2 induced cytotoxic t-lymphocyte-associated protein 4 regulates aspergillus-induced regulatory T-cells with pro-inflammatory characteristics. Sci. Rep. 2017, 7, 11500. [CrossRef] [PubMed]

121. Zielinski, C.E.; Mele, F.; Aschenbrenner, D.; Jarrossay, D.; Ronchi, F.; Gattorno, M.; Monticelli, S.; Lanzavecchia, A.; Sallusto, F. Pathogen-induced human Th17 cells produce IFN-gamma or IL-10 and are regulated by IL-1 $\beta$. Nature 2012, 484, 514-518. [CrossRef] [PubMed]

122. Gresnigt, M.S.; Becker, K.L.; Smeekens, S.P.; Jacobs, C.W.; Joosten, L.A.; van der Meer, J.W.; Netea, M.G.; van de Veerdonk, F.L. Aspergillus fumigatus-induced IL-22 is not restricted to a specific th cell subset and is dependent on complement receptor 3. J. Immunol. 2013, 190, 5629-5639. [CrossRef] [PubMed]

2017 by the authors. Licensee MDPI, Basel, Switzerland. This article is an open access article distributed under the terms and conditions of the Creative Commons Attribution (CC BY) license (http://creativecommons.org/licenses/by/4.0/). 